\title{
ANALISIS FAKTOR-FAKTOR YANG MEMPENGARUHI PENGELOLAAN ASET DI INSTITUT PEMERINTAHAN DALAM NEGERI KAMPUS PAPUA
}

\author{
Juliessi Paranga \\ Juliessi40@gmail.com
}

\begin{abstract}
Abstrak
The purpose of this study is to investigate the assets management in the Papua Campus of Institut Pemerintahan Dalam Negeri (IPDN). The research also wants to reveal how the influence of Legal Audit, Human Resources and Leadership Commitments on Optimizing Asset Management. We surveyed on this Campus by selecting a sample of 30 respondents. We empirically tested our hypothesis using Multiple Regression Analysis. The results show that the assets management on this Campus is proper and running under the appropriate statutes. Still, there are needs for more advance and thought in the assets administration, utilization and supervision. Legal audit proved to have a positive but not significant effect on asset management. It means that the audit does not guarantee asset optimization. Human resources and leadership commitments have a positive and significant impact on asset management, reflects that if human resources and leadership commitments are getting more robust, asset management will also be more trustworthy.
\end{abstract}

Keywords: Legal audit, human resources, leadership commitment and asset management

\section{PENDAHULUAN}

Manajemen Aset merupakan salah satu topik yang menarik didiskusikan. Setiap organisasi swasta maupun organisasi publik tentunya memiliki aset, baik aset yang berwujud (tangible) maupun aset yang tidak berwujud (intangibles). Pengelolaan aset menjadi salah satu hal penting dalan penyelenggaraan organisasi public seperti pemerintahan, baik pemerintah pusat maupun pemerintah daerah. Saat ini lembaga pemerintahan semakin dituntut untuk bekerja yang baik, efektif dan efisien serta penciptaan akuntabilitas publik dapat diciptakan melalui pengelolaan aset yang baik. Artinya upaya-upaya melakukan pengelolaan aset secara baik merupakan salah satu upaya untuk dapat menciptakan good governance.

Menurut Permendagri nomor 19 Tahun 2016 pengelolaan Barang Milik Negara adalah keseluruhan kegiatan yang meliputi perencanaan kebutuhan dan penganggaran, pengadaan, penggunaan, pemanfaatan, pengamanan dan pemeliharaan, penilaian, 
pemindahtanganan, pemusnahan, pengahapusan, penatausahaan dan pembinaan, pengawasan dan pengendalian.

Pengelolaan aset menjadi salah satu hal penting dalam penyelenggaraan Pemerintahan Pusat maupun Pemerintahan Daerah saat ini karena pemerintahan baik, efektif dan efisien serta penciptaan akuntabilitas publik dapat diciptakan melalui pengelolaan aset yang baik. Pengelolaan aset bukan merupakan pekerjaan yang mudah. Berdasarkan Ikhtisiar Hasil Pemerikasaan Semester I Tahun Anggaran 2018 yang dirilis oleh Badan Pemeriksa Keuangan (BPK), bahwa banyak entitas pemerintah yang masih bermasalah dengan aset tetap. Menurut Hidayati, Darmayanti, Yeasy, \& Maihendri (2016), lemahnya pengelolaan Barang Milik Negara/Daerah merupakan faktor yang menyebabkan masih banyaknya pemerintah daerah memperoleh tidak memperoleh opini Wajar Tanpa Pengecualian (WTP). Bahkan pada kasus tertentu, ada sejumlah daerah mengalami penurunan opini BPK yang disebabkan kurang mampu mewujudkan tata kelola aset/barang pemerintah secara baik (Nahartyo, 2013; Salle, 2019).

Permasalahan dalam pengelolaan aset seperti tidak jelas status hukum aset, pemanfaatan aset oleh pihak lain yang tidak mengikuti prosedur, tukar-menukar aset, pencatatan aset yang tidak tertib, konflik kepentingan dalam pemanfaatan aset, terbatasnya tenaga Sumberdaya Manusia (SDM) yang menyajikan laporan keuangan, kebijakan untuk pengelolaan aset yang belum mengakomodir semua hal yang diperlukan, penguasaan dan pemeliharaan aset agar tidak hilang, rusak atau dicuri, dan sebagainya. Permasalahanpermasalahan tentang aset mengenai pengelolaan aset ini harus segera diselesaikan, walaupun belum sempurna namun harus ada pembenahan dalam penataannya karena aset merupakan kekayaan yang harus dipelihara, diamankan dan dimanfaatkan sebaik-baiknya sebagai amanah yang harus diemban untuk masyarakat. Oleh karena itu, pemerintah harus pandai dan terampil dalam mengelola aset atau barang milik Negara/daerah dan dituntut untuk membenahi sistem pengelolaan aset dengan berpedoman pada regulasi dan undangundang yang berlaku. 
Aset atau barang milik Negara/daerah itu sendiri dikelola oleh unit organisasi yang memiliki hak dan tanggung jawab atas aset tersebut. Pengelola aset atau barang milik Negara/daerah adalah pejabat yang berwenang dan bertanggungjawab menetapkan kebijakan dan pedoman serta melakukan pengelolaan barang milik negara/daerah. Pengelolaan aset atau barang milik negara/daerah dituntut untuk mampu secara profesional dan mendiri mengelola asetnya melalui kemampuan manajemen aset yang terbagi dalam 5 (lima) tahapan kerja, yaitu : Inventarisasi aset, legal audit, penilaian aset, optimalisasi aset serta pengawasan dan pengendalian dengan pengembangan Sistem Informasi Manajemen Aset (SIMA).

Menghadapi persoalan pengelolaan aset perlu proses yang cukup panjang, pemerintah pusat atau daerah dituntut untuk bekerja keras dalam pelaksanaannya sehingga tujuan tersebut bias tercapai. Untuk mencapai hal tersebut tentunya bukan perkara yang mudah, karena banyak yang harus diperbaharui dan diperbaiki. Struktur pemerintahan merupakan elemen utama yang harus diperbaiki dan diperbaharui, karena dengan struktur yang baik akan menghasilkan pekerjaan yang baik, begitu pula sebaliknya. Semuanya harus dilihat dari tugas pokok dan fungsinya dan harus disesuaikan dengan pejabat yang diperlukan, sehingga terjadi pemerintahan yang kaya struktur tapi miskin fungsi, dan tidak juga tidak terjadi sebaliknya kaya fungsi tapi miskin struktur, harus seimbang antara keduanya. Peraturan perundang-undangan tentang pengelolaan aset juga harus dipertegas, selama ini peraturan yang ada hanyalah mengenai teknis pengelolaan dan tidak ada peraturan perundang-undangan yang mengatur tentang hukuman atau punishment kepada pemerintah yang melalaikan tupoksinya.

Institut Pemerintahan Dalam Negeri (IPDN) Kampus Papua juga menghadapi permasalahan pengelolaan Aset atau barang milik Negara karena kurangnya pegawai yang memahami pengelolaan aset, pemahaman yang kurang tentang peraturan perundangundangan tentang pengelolaan aset yang berlaku, koordinasi antar individu maupun bagian lain yang bekaitan dengan pengelolaan aset dan komitmen pimpinan untuk meningkatkan kualitas pengelolaan aset. 
IPDN kampus Papua memiliki jumlah aparatur yang di bagi menjadi 2 (dua) yaitu Pegawai negeri sipil (PNS) yang berjumlah 35 Orang dan Tenaga harian lepas (THL) yang berjumlah 90 orang, dengan jumlah keseluruha pegawai yaitu berjumlah 125 orang pegawai, yang di bagi dalam 3 bagian dan 9 unit kerja yang ada di IPDN kampus papua. Jumlah pegawai yang dimiliki IPDN Kampus Papua sudah cukup memadai dengan tingkat pendidikan pegawainya yang juga baik, namun masih kurangnya pegawai yang khususnya menangani pengelolaan aset di IPDN Kampus Papua dan juga kurangnya pemahaman dan pengelolaan aset, hal ini juga dikarenakan kurangnya pendidikan dan pelatihan yang diberikan kepada pegawai untuk bisa mengelola aset secara benar.

Seringkali juga didapati pemindahan aset dari satu bagian kebagian lain atau ke unit lain dan sebaliknya yang tidak tercatat dengan baik, karena tidak diketahui oleh pengelola aset bahwa aset tersebut sudah dipindahkan tanpa sepengetahuan pengelolaan aset untuk di catat, belum adanya kartu inventaris ruangan pada setiap ruangan yang ada di IPDN Kampus Papua yang menjadi permasalahan pengelolaan aset, serta kurangnya perhatian dan tanggung jawab dari pengguna aset itu untuk menjaga dan memelihara aset yang dipakainya. Permasalahan legal yang sering ditemui misalnya status hak penguasaan yang lemah, aset dikuasai pihak lain, pemindahtanganan aset yang tidak termonitor dan lain-lain. Kurangnya pengawasan dalam pengelolaan aset inilah yang menjadi penyebab utama mengapa permasalahan-permasalahan aset ini sering terjadi, aset yang banyak menjadi permasalahan di IPDN Kampus Papua adalah berupa aset mesin dan peralatan. Untuk mengetahui mengapa pengelolaan aset di IPDN Kampus Papua masih rendah berdasarkan hal-hal yang dijelaskan diatas maka penelitian ini mencoba menganalisa faktor-faktor apa saja yang mempengaruhi rendahnya pengelolaan aset di IPDN Kampus Papua baik dalam perencanaan, pelaksanaan dan pengawasannya.

Berdasarkan permasalahan yang diuraikan di atas, maka rumusan masalah pada penelitian ini adalah : (1) Bagaimana pengelolaan aset di IPDN Kampus Papua ? (2) Bagaimana pengaruh Legal Audit, Sumber Daya Manusia dan Komitmen Pimpinan terhadap Pengelolaan Aset di IPDN Kampus Papua. 


\section{LANDASAN TEORI DAN PENGEMBANGAN HIPOTESIS}

\section{Aset Tetap}

Aset adalah semua kekayaan yang dimiliki oleh pemerintah, baik yang berwujud maupun yang tidak berwujud yang dapat dinilai dengan satuan mata uang dan digunakan dalam operasional pemerintahan. Berdasar Peraturan Pemerintah Nomor 71 Tahun 2010 tentang Standar Akuntasi menjelaskan aset adalah sumber daya ekonomi yang dikuasai atau dimiliki oleh pemerintah sebagai akibat dari peristiwa masa lalu dan dari mana manfaat ekonomi atau sosial di masa depan diharapkan dapat diperoleh, baik oleh pemerintah maupun masyarakat, serta dapat diukur dengan satuan uang, termasuk sumber daya non keuangan yang diperlakukan untuk penyediaan jasa bagi masyarakat umum dan sumbersumber daya yang dipelihara karena alasan sejarah dan budaya. Aset tetap mempunyai masa manfaat lebih dari 12 bulan.

Aset tetap pemerintah diklasifikasikan berdasarkan kesamaan dalam sifat atau fungsinya dalam aktivitas operasi entitas terdiri dari: tanah, gedung, bangunan, peralatan dan mesin, jalan, irigasi, dan jaringan, aset tetap lainnya, serta kontruksi dalam pengerjaan (PP 71/2010). Tanah yang dikelompokkan sebagai aset tetap adalah tanah yang diperoleh dengan maksud untuk dipakai dalam kegiatan operasional pemerintah dan dalam kondisi siap pakai. Gedung dan bangunan mencakup seluruh gedung dan bangunan yang diperoleh dengan maksud untuk dipakai dalam kegiatan operasional pemerintah dan dalam kondisi siap pakai. Peralatan dan mesin mencakup mesin-mesin dan kendaraan bermotor, alat elektronik, dan seluruh inventaris kantor, dan peralatan lainnya yang nilainya signifikan dan masa manfaatnya lebih dari 12 bulan dan dalam kondisi siap pakai. Jalan, irigasi, dan jaringan mencakup jalan, irigasi, dan jaringan yang dibangun oleh pemerintah serta dimiliki dan/atau dikuasai oleh pemerintah dan dalam kondisi siap dipakai. Aset tetap lainnya mencakup aset tetap yang tidak dapat dikelompokkan ke dalam kelompok aset tetap di atas. Golongan aset antara lain adalah buku perpustakaan, buku terbitan berkalah, barang-barang perpustakaan, barang bercorak kesenian atau kebudayaan, serta hewan ternak dan tumbuh 
tumbuhan. Konstruksi dalam pengerjaan mencakup aset tetap yang sedang dalam proses pembangunan namun pada tanggal laporan keuangan belum selesai seluruhnya. Aset ini dicatat sebesar biaya yang dikeluarkan sampai dengan akhir masa pengerjaan pada tahun yang bersangkutan. Aset tetap yang tidak digunakan untuk keperluan operasional pemerintah tidak memenuhi definisi aset tetap dan harus disajikan di pos aset lainnya sesuai dengan nilai tercatatnya.

\section{Manajemen Aset}

Dalam rangka mewujudkan tertib administrasi terhadap pengelolaan barang daerah perlu diatur pedoman kerjanya, untuk itu telah dikeluarkan Peraturan Menteri Dalam Negeri No. 19 Tahun 2016 (Permendagri 19/2016). Dalam Peraturan Menteri Dalam Negeri tersebut dimaksud dengan Barang Milik Daerah adalah semua barang yang dibeli atau diperoleh atas beban Anggaran Pendapatan dan Belanja Daerah atau perolehan lainnya yang sah.

Permendagri 19/2016 pada Pasal 6 menjelaskan barang milik daerah yang berasal dari perolehan lainnya yang sah, meliputi: (a) barang yang diperoleh dari hibah/sumbangan atau yang sejenis; (b) barang yang diperoleh sebagai pelaksanaan dari perjanjian/kontrak; (c) barang yang diperoleh berdasarkan ketentuan peraturan perundang-undangan; (d) barang yang diperoleh berdasarkan putusan pengadilan yang telah mempunyai kekuatan hukum tetap; atau (e) barang yang diperoleh kembali dari hasil divestasi atas penyertaan modal pemerintah daerah.

Hasfi (2013) menjelaskan bahwa dalam pengelolaan barang milik daerah wajib memperhatikan beberapa enam azas. Pertama, azas fungsional, yaitu pengambilan keputusan dan pemecahan masalah di bidang pengelolaan barang milik daerah yang dilaksanakan oleh kuasa pengguna barang, pengguna barang, pengelola barang dan Kepala Daerah sesuai fungsi, wewenang dan tanggung jawab masing-masing. Kedua, azas kepastian hukum, yaitu pengelolaan barang milik daerah harus dilaksanakan berdasarkan hukum dan peraturan perundang-undangan. Ketiga, azas transparansi, yaitu penyelenggaraan pengelolaan barang milik daerah harus transparan terhadap hak 
masyarakat dalam memperoleh informasi yang benar. Empat, azas efisiensi, yaitu pengelolaan barang milik daerah diarahkan agar barang milik daerah digunakan sesuai batasan-batasan standar kebutuhan yang diperlukan dalam rangka menunjang penyelenggaraan tugas pokok dan fungsi pemerintahan secara optimal, Kelima, azas akuntabilitas, yaitu setiap kegiatan pengelolaan barang milik daerah harus dapat dipertanggung jawabkan kepada rakyat. Keenam, azas kepastian nilai, yaitu pengelolaan barang milik daerah harus didukung oleh adanya ketepatan jumlah dan nilai barang dalam rangka optimalisasi pemanfaatan dan pemindahtanganan barang milik daerah serta penyusunan neraca Pemerintah Daerah.

Setiap intitusi di dunia tentunya memiliki karakteristik manajemen masing-masing yang dipercaya dapat memenuhi segala kebutuhan dalam usaha mencapai tujuan institusi tersebut. Konsep New Public Management (NPM) merupakan isu penting dalam reformasi sektor publik saat ini. NPM mempunyai fokus yang sangat kuat terhadap internal organisasi, dalam artian bahwa NPM berusaha memperbaiki kinerja sektor publik dengan menggunakan metode yang biasa digunakan oleh sektor privat.

Beberapa elemen utama dalam penerapan sistem administrasi publik model NPM meliputi desentralisasi kekuasaan pelayanan publik termasuk outsourcing dan privatisasi; rasionalisasi; deregulasi, dan peningkatan kapasitas bagi staf lembaga pemerintah; berorientasi pada hasil (kinerja), kompetisi penyediaan jasa publik; dan budaya manajemen yang berorientasi pada pelanggan dan akuntabilitas publik berdasarkan kinerja Pollitt \& Bouckaert (2004).

Good Governance sebagai salah satu bentuk manajemen pembangunan, yang juga disebut sebagai administrasi pembangunan, yang menempatkan peran pemerintah sentral yang menjadi Agent of Change dari suatu masyarakat berkembang/developing di dalam negara berkembang. Agent of Change karena perubahan yang dikehendakinya, menjadi planned change (perubahan yang berencana), maka disebut juga Agent of Development. Agent of Development diartikan sebagai pendorong proses pembangunan dan perubahan masyarakat bangsa. 
Penerapan prinsip-prinsip Good Governance merupakan suatu keharusan bagi pelaksana pengelolaan barang milik negara, hal ini disebutkan dalam Peraturan Pemerintah Nomor 27 Tahun 2014 pasal 3 yang berbunyi Pengelolaan Barang Milik Negara dilaksanakan berdasarkan asas fungsional, kepastian hukum, transparansi, efisiensi, akuntabilitas dan kepastian nilai (Salle, Mesak, \& Yund, 2015).

Lu (2011) menyebutkan pentingnya penerapan prinsip good gevernance dalam manajemen aset tetap. Penerapan dalam pengawasan manajemen aset tetap dapat dilakukan dalam beberapa hal, yaitu pengawasan ketaatan terhadap peraturan perundangan, pengawasan terhadap akuntabilitas finansial. Manajer harus memiliki respontabilitas, integritas dan transparansi dalam melaksanakan manajemen aset tetap yang baik, sehingga keputusan dalam manajemen aset tetap dapat dipertanggung jawabkan terhadap internal dan eksternal stakeholder dan untuk menjamin bahwa manajemen aset tetap dilaksanakan secara efisien dan efektif serta akuntabel. Menurut Ouda (2016) bahwa public sector assets management harus memenuhi syarat good governance diantaranya transparency, accountability, and openness in reporting and disclousure of information. Sedangkan menurut Grubišić, Nušinović, \& Roje (2009) prinsip transparansi, professional dan responsible adalah syarat utama untuk efisiensi public sector assets management. Menurut Mardiasmo \& MBA (2009) terdapat tiga prinsip dasar pengelolaan kekayaan asset Negara yakni: (1) adanya perencanaan yang tepat, (2) pelaksanaan/pemanfaatan yang efisiensi dan efektif, dan (3) pengawasan (monitoring).

Berdasarkan Peraturan Menteri Dalam Negeri Nomor 17 Tahun 2007 tentang Pedoman Teknis Pengelolaan Barang Milik Negara/Daerah, Pengelolaan Barang Milik Negara/Daerah meliputi sebagai berikut : (1) perencanaan kebutuhan dan penganggaran; (2) pengadaan; (3) enerimaan, penyimpanan dan penyaluran; (4) penggunaan; (5) penatausahaan; (6) pemanfaatan; (7) pengamanan dan pemeliharaan; (8) penilaian; (9) penghapusan; (10) pemindahtanganan; (11) embinaan, pengawasan dan pengendalian; (12) Pembiayaan; dan (13) tuntutan ganti rugi. 


\section{Sumber Daya Manusia}

Sumber daya manusia (SDM) mempunyai posisi sentral dalam mewujudkan kinerja pembangunan, yang, yang menempatkan manusia dalam fungsinya sebagai resource pembangunan. Dalam kontek ini, harga dan nilai manusia ditentukan oleh relevansi kontruksinya pada proses produk. Kualitas manusia diprogramkan sedemikian agar dapat sesuai dengan tuntutan pembangunan atau tuntutan masyarakat Moelyarto (1995). Eksistensi bangsa Indonesia di tengah percaturan era global sekarang, akan dipengaruhi kemampuan sumber daya manusia Indonesia, terutama yang bercirikan kemampuan penguasaan ilmu pengetahuan dan teknologi dan pemantapan iman dan taqwa terhadap Tuhan Yang Maha Esa Ash-Shidiqie (1996).

Salah satu sumber daya yang penting dalam manjemen adalah sumber daya manusia atau human resource. Pentingnya sumber daya manusia ini, perlu disadari oleh semua tingkatan manajemen termasuk juga manajemen pendidikan Islam. Bagaimanapun majunya teknologi saat ini, namun faktor manusia tetap memegang peranan penting bagi keberhasilan suatu organisasi. Bahkan dapat dikatakan bahwa manajemen itu pada hakikatnya adalah manajemen sumber daya manusia atau manajemen sumber daya manusia adalah identik dengan manajemn itu sendiri. Hakikat sumber daya manusia setiap organisasi atau perusahaan, khususnya pada lembaga pendidikan diperlukan adanya sumber daya manusia sebagai tenaga kerja. Oleh sebab itu, yang dimaksud dengan sumber daya manusia adalah tenaga kerja pada suatu organisasi Mukhyi \& Hudiyanto (1995). Dari pendapat tersebut jelas bahwa sumber daya manusia adalah tenaga kerja yang menduduki suatu posisi atau orang-orang yang mempunyai tanggung jawab untuk melaksanakan tugas atau pekerjaan pada suatu organisasi tertentu. Oleh karena itu, menurut Mukhyi bahwa hal yang penting untuk diperhatikan oleh organisasi adalah bagaimana memperoleh tenaga kerja sesuai dengan kebutuhan dan posisi yang akan diduduki, bagaimana mengembangkannya dan memelihara tenaga kerja, menggunakan serta mengevaluasi hasil kerjanya Mukhyi \& Hudiyanto (1995). 
Dalam prespektif Islam, pendidikan memainkan peran penting dalam upaya melahirkan manusia yang handal dan dapat menjawab tantangan zaman. Sumber daya manusia tersebut merupakan gerakan human investment. Human invesment adalah upaya pendidikan jangka panjang untuk melahirkan sumber daya manusia Yasmadi (2002). Pengembangan sumber daya manusia bukan merupakan persoalan yang mudah karena membutuhkan pemikiran, langkah aksi yang sistematik, dan serius. Karena berusaha memberikan konstruksi yang utuh tentang manusia dengan mengembangkan seluruh potensi dasar manusia dan bagaimana aktifnya. Dalam pengetahuan manajemen, falsafah sebenarnya menyediakan seperangkat pengetahuan (a body of related knowldge) untuk berpikir efektif dalam memecahkan masalah-masalah manajemen Fattah (2004). Hal ini merupakan hakikat manajemen sebagai suatu disiplin ilmu dalam mengatasi masalah organisasi berdasarkan pendekatan yang integral.

Nur Izzaty (2011) mengemukakan pengertian sumber daya manusia adalah orangorang yang siap, mempunyai keinginan, dan mampu untuk berkontribusi dalam tujuan organisasi. Menurut Nur Izzaty (2011) sumber daya manusia berkualitas tinggi adalah sumber daya manusia yang mampu menciptakan bukan saja nilai komparatif, tetapi juga nilai kompetitif-generatif inovatif dengan menggunakan energi tertinggi seperti intelligence, creativity, dan imagination, tidak lagi semata-mata menggunakan energi kasar seperti bahan mentah, lahan, air, tenaga otot dan sebagainya. Untuk itu dibutuhkan latar belakang pendidikan yang jelas dan terukur. Latar belakang pendidikan mempunyai peran yang sangat penting karena dengan pengetahuan yang diperoleh dari pendidikan dalam proporsi tertentu diharapkan dapat memenuhi syarat-syarat yang dituntut oleh suatu pekerjaan dapat diselesaikan dengan lebih cepat dan tepat.

\section{Legal Audit}

Legal audit dilakukan untuk mendapat jaminan atas keamanan aset, apakah aset telah memenuhi tuntutan aspek hukum. Siregar (2004) menyatakan bahwa legal audit merupakan satu lingkup kerja manajemen aset berupa inventarisasi status penguasaan aset, 
system dan prosedur penguasaan aset atau pengalihan aset, identifikasi dan mencari solusi atas permasalahn legal, strategi untuk memecahkan berbagai permasalahan legal yang terkait dengan penguasaan ataupun pengalihan aset.

Gima (2013) menyatakan legal audit aset atau uji tuntas hukum dilaksanakan untuk mengetahui secara pasti kondisi aspek legal aset. Lebih lanjut legal audit aset didefinisikan sebagai pemeriksaan aset untuk memperoleh gambaran secara jelas dan menyeluruh terutama mengenai status kepemilikan, system dan prosedur pemeriksaan (penggunaan dan pemanfaatan), pengalihan aset, mengidentifikasi kemungkinan terjadinya berbagai permasalahan hukum, serta mencari solusi atas masalah hukum tersebut. Manfaat legal audit aset antara lain adalah meminimalisasi resiko hukum, mengoptimalkan penggunaan dan pemanfaatan aset, identifikasi dini permasalahan yang mungkin terjadi dan menyelesaikan berbagai masalah yang timbul menyangkut aspek hukum Gima (2013).

Peraturan Pemerintah Nomor 27 Tahun 2014 tidak mengatur mengenai legal audit, melainkan mengatur tentang pengamanan Barang Milik Daerah yang wajib dilakukan oleh Pengelola Barang, Pengguna Barang dan/atau Kuasa Pengguna Barang. Pengamanan Barang Milik Daerah mencakup pengamanan administrasi, pengamanan fisik, dan pengamanan hukum.

Dalam Peraturan Menteri Dalam Negeri Nomor 17 Tahun 2007 Tentang Pedoman Teknis Pengelolaan Barang Milik Daerah menjelaskan bahwa legal audit juga merupakan tindakan pengamanan atau tindakan pengendalian, penertiban dalam upaya pengurusan barang daerah secara fisik, administrasi dan tindakan hukum. Pengamanan tersebut menitik beratkan pada penertiban pengamanan secara fisik dan secara administrasi, sehingga barang daerah tersebut dapat dipergunakan/dimanfaatkan secara optimal serta terhindar dari penyerobotan pengambil alihan atau kalim dari pihak lain. Pengaman secara fisik terhadap barang tidak bergerak (tanah dan bangunan) dapat dilakukan dengan pemagaran, pemasangan papan tanda kepemilikan dan penjagaan. Pengaman secara administrtif dapat dilakukan dengan cara penyelesaian bukti kepemilikan seperti IMB, berita acara serah terima, surat perjanjian, akte jual beli dan dokumen pendukung lainnya. 


\section{Komitmen Pimpinan}

Teori yang mendasari komitmen adalah teori komitmen organisasi. Komitmen organisasi sudah mulai diperkenalkan oleh Etzioni (1961). Istilah ini semakin populer sejak tahun 1977 setelah dibahas oleh Staw dan Salancik, yang mengajukan dua bentuk komitmen, yaitu komitmen sikap (attitudinal commitment) dan komitmen tingkah laku (behavioral commitment). Komitmen sikap adalah keadaan dimana individu mempertimbangkan sejauhmana nilai dan tujuan organisasi, serta sejauhmana keinginannya untuk mempertahankan keanggotannya dalam organisasi. Komitmen tingkah laku didasarkan pada sejauhmana karyawan menetapkan keputusan untuk terikat pada organisasi berkaitan dengan adanya kerugian jika memutuskan melakukan alternative lain diluar pekerjaannya saat ini.

Jika seseorang ingin menjadi seorang pemimpin yang efektif, pemimpin harus memiliki komitmen. Komitmen menunjukkan kepada orang lain bahwa seseorang memiliki keyakinan. Komitmen memiliki 3 (tiga) sifat Maxwell (2001:31). Pertama, komitmen dimulai didalam hati jika seseorang ingin membuat perbedaan dalam kehidupan orang lain tersebut harus lebih dahulu memeriksa hatinya apakah sudah benar-benar berkomitmen. Kedua, komitmen diuji oleh perbuatan, satu-satunya ukuran sejati dari komitmen adalah perbuatan. Jadi komitmen harus diiringi oleh perbuatan. Ketiga, komitmen membuka pintu menuju prestasi, komitmen berlawanan dengan penolakan, karena komitmen adalah janji serius untuk terus maju dan untuk bangkit. Jadi jika seseorang ingin mencapai suatu tujuan maka harus punya komitmen.

Komitmen adalah suatu keteguhan untuk berjanji kepada diri sendiri yang akan memacu dan merangsang seseorang untuk terus berjuang dalam mencapai target yang dicita-citakan serta tidak akan berhenti sebelum target yang dicita-citakan tercapai. Leadership (kepemimpinan) merupakan faktor pertama yang menjadi kunci keberhasilan kinerja suatu organisasi. Kesuksesan sutau organisasi tergantung pada kinerja para pegawai yang berada paling bawah dalam suatu piramida organisasi, karena pada dasarnya para pegawai yang bekerja membutuhkan pemimpin yang memimpin mereka dalam bekerja. Oleh 
karena itu, berbagai kebijakan pelayanan prima akan dapat berjalan dengan baik apabila terdapat dukungan dari top management yang ada didalam organisasi tersebut.

Menurut Mulyanto (2015) ada 5 (lima) prinsip kunci dalam membangun komitmen yaitu : (1) memelihara atau meningkatkan harga diri. Artinya pimpinan harus pintar menjaga agar harga diri bawahannya tidak rusak, (2) memberikan tanggapan dengan empati, (3) meminta bantuan dan mendorong keterlibatan. Artinya pegawai selain butuh dihargai juga ingin dilibatkan dalam pengambilan keputusan, (4) mengungkapkan pikiran, perasaan dan rasional, (5) memberikan dukungan tanpa mengambil alih tanggung jawab. Prinsip tersebut mencerminkan falsafah kepemimpinan dimana pimpinan menawarkan bantuan agar pegawai dapat melaksanakan tugas dengan baik, dan perlu diingat bahwa fungsi pimpinan hanya membantu, tanggung jawab tetap ada pada masing-masing pegawai.

Pemimpin yang efektif akan dapat menjalankan fungsinya dengan baik, tidak hanya ditunjukkan dari kekuasaan yang dimiliki tetapi juga ditunjukkan pula oleh perhatian pemimpin terhadap kesejahteraan dan kepuasan karyawan terhadap pemimpin dan peningkatan kualitas karyawan. Sejak setengah abad yang lalu, teori dan penilaian tentang kepemimpinan hanya ditujukan pada model autokratik atau demokratik, direktif atau parsipatif Bass \& Avolio (1990).

\section{Hipotesis Penelitian}

Berdasarkan perumusan masalah, tujuan penulisan, landasan teori, kajian empiris dan kerangka konseptual maka dapat diajukan hipotesis penelitian sebagai berikut; kajian ini didasarkan pada beberapa kajian empiris utama yakni; Raharja (2015) menyatakan bahwa Sumber daya manusia yang kurang berkualitas merupakan salah satu penghambat untuk dapat melaksanakan pengelolaan keuangan dan aset daerah yang baik. Sumber daya manusia yang masih kurang bukan hanya Dalam Badan Pengelolaan Keuangan Dan Aset Daerah (BPKAD) Kabupaten Lamongan tetapi juga dalam setiap Satuan Kerja Perangkat Daerah (SKPD). Sedangkan koordinasi dan hubungan kerja sama yang rendah baik antar individu maupun dengan instansi lain yang berkaitan dengan pengelolaan keuangan dan 
aset daerah dapat menghambat pelaksanaan pengelolaan keuangan dan aset daerah dengan baik.

Selanjutnya Simamora \& Halim (2015) melalui hasil kajiannya menyatakan bahwa ; Sumber daya manusia, bukti kepemilikan, penilaian aset, komitmen pimpinan. Sikap diperlukan dalam mengelola aset Pemerintah Kabupaten Tapanuli Selatan.

Selanjutnya Pauweni et al. (2017) melalui hasil kajiannya menyatakan bahwa; inventaris aset, kualitas sumber daya manusia, optimalisasi pengelolaan aset berpengaruh positif dan signifikan terhadap optimalisasi pengelolaan aset sedangkan komitmen kepemimpinan berpengaruh positif tetapi tidak signifikan terhadap kualitas laporan keuangan Pemerintah Daerah Kabupaten Takalar.

Berdasarkan uraian hasil kajian empiris yang telah dikemukakan, maka hipotesis penelitian yang dikemukakan adalah diduga;

$\mathrm{H} 1 \quad$ : Legal Audit berpengaruh positif dan signifikan terhadap optimalisasi pengelolaan aset pada IPDN Kampus Papua.

H2 : Kompetensi Sumber daya Masnusia berpengaruh positif dan signifikan terhadap optimalisasi pengelolaan aset pada IPDN Kampus Papua.

H3 : Komitmen Pimpinan berpengaruh positif dan signifikan terhadap optimalisasi pengelolaan aset pada IPDN Kampus Papua.

H4 : Legal Audit, Sumber daya manusia dan Komitmen Pimpinan berpengaruh positif dan signifikan terhadap optimalisasi pengelolaan aset di IPDN Kampus Papua

\section{METODE PENELITIAN}

Metode yang dilakukan dalam penelitian ini adalah menggunakan mixed method yang menggabungkan pendekatan kualitatif dan kuantitatif. Rancangan pengumpulan data adalah metode survey. Jenis penelitian ini adalah penelitian assosiatif kausal yaitu penelitian yang bertujuan untuk mengetahui hubungan yang bersifat sebab akibat. 
Fokus penelitian yaitu pada Analisis Faktor-Faktor yang mempengaruhi pengelolaan aset. Penelitian ini dilakukan dengan melakukan observasi dan wawancara kepada informan secara mendalam yang dianggap memiliki kapasitas dalam memberikan informasi tentang bagaimana pengelolaan aset dan permasalahan-permasalahan yang terjadi. Fokus penelitian ini adalah agar ruang lingkup peneliti tidak luas dan lebih fokus untuk mencapai tujuan yang telah ditetapkan.

Data yang digunakan dalam penelitian ini meliputi 2 (dua) jenis data yaitu data primer dan data sekunder. Data primer adalah data yang diperoleh langsung oleh peneliti dari objek penelitian. Data ini dikumpulkan dengan menggunakan kuisoner yang disebarkan pada responden dan wawancara langsung dengan semua responden. Data Sekunder adalah data yang didapatkan dari pihak ketiga secara langsung, dalam bentuk laporan, catatan, dan dokumen melalui kantor tempat penelitian, serta melalui studi melalui kepustakaan, peraturan Perundangundangan, dan buku-buku yang relevan lainnya.

Yang menjadi populasi dalam penelitan ini adalah seluruh pegawai di Institut Pemerintahan Dalam Negeri Kampus Papua yang terdiri dari 35 orang Pegawai Negeri Sipil (PNS), 90 orang Tenaga Harian Lepas (THL), jumlah seluruh pegawai di IPDN Kampus Papua adalah sebanyak 125 orang. Dari populasi tersebut diambil sebagian untuk ditetapkan sebagai sampel dengan menggunakan teknik purposive. Jumlah sampel 30 orang.

Pengukuran variebel penelitian menggunakan skala Likert. Menurut Sugiyono (2013) skala Likert digunakan untuk mengukur sikap, pendapat dan persepsi seseorang atau sekelompok orang tentang fenomena sosial. Dalam penelitian, fenomena sosial ini telah ditetapkan secara spesifik oleh peneliti, yang selanjutnya disebut sebagai variabel penelitian. Dengan skala likert, maka variabel yang akan diukur dijabarkan menjadi indikator variabel. Kemudian indikator tersebut dijadikan sebagai titik tolak untuk menyusun item-item instrumen yang dapat berupa pernyataan atau pertanyaan.

Studi ini menganalisis data menggunakan analisis regresi berganda. Menurut Ghozali (2013:96) analisis regresi digunakan untuk mengukur kekuatan hubungan antara dua variabel atau lebih, juga menunjukan arah hubungan antara variabel dependen dengan 
independen. Analisis regresi linier berganda adalah hubungan secara linier antara dua atau lebih variable independen $(\mathrm{X})$ dengan dengan variabel dependen $(\mathrm{Y})$. Analisis ini untuk memprediksi nilai dari variabel dependen apabila nilai variabel independen mengalami kenaikan atau penurunan dan untuk mengetahui arah hubungan,antara variabel independen dengan variabel dependen apakah masingmasing variabel independen berhubungan positif atau negatif. Model regresi linear berganda pada penelitian ini sebagai berikut :

$$
\mathrm{Y}=\mathrm{a}+\mathrm{b} 1 \mathrm{X} 1+\mathrm{b} 2 \mathrm{X} 2+\mathrm{b} 3 \mathrm{X} 3+\mathrm{e}
$$

Keterangan :

$$
\begin{aligned}
& \mathrm{Y}=\text { = Variabel Bebas ( Pengelolaan aset) } \\
& \text { a }=\text { Konstanta } \\
& \text { b1 } \mathrm{s} / \mathrm{d} \text { b3 = Parameter Koefisien Regresi } \\
& \mathrm{X} 1=\text { Legal Audit } \\
& \text { X2 }=\text { Sumber daya Manusia } \\
& \text { X3 }=\text { Komitmen Pimpinan } \\
& \mathrm{e}=\text { error }
\end{aligned}
$$

\section{HASIL PENELITIAN DAN PEMBAHASAN}

\section{Hasil Penelitian}

Pada bagian akan dijelaskan tentang gambaran karakteristik responden sebanyak 30 pegawai Institut Pemerintahan Dalam Negeri (IPDN) Kampus Papua berdasarkan tingkat pendidikan dan masa kerja yang pembahasannya di bawah ini.

Pendidikan menunjukkan pencapaian keilmuan seseorang yang dapat dijadikan sebagai indikator efektivitas kinerja. Pengelompokan tingkat pendidikan terakhir pegawai Institut Pemerintahan Dalam Negeri (IPDN) Kampus Papua dibagi atas; pendidikan tingkat SMA/sederajat, Diploma, S1, S2 dan S3. Secara lengkap karakteristik responden berdasarkan tingkat pendidikan dijelaskan pada Tabel 1 berikut ini. 
Tabel 1

Karakteristik Responden Berdasarkan Tingkat Pendidikan

\begin{tabular}{|l|c|c|}
\hline \multicolumn{1}{|c|}{ Tingkat Pendidikan } & Jumlah & Persentase \\
\hline SMA/Sederajat & 3 & $10,0 \%$ \\
\hline Diploma & 7 & $23,3 \%$ \\
\hline S1 & 10 & $33,3 \%$ \\
\hline S2 & 9 & $30,3 \%$ \\
\hline S3 & 1 & $3,3 \%$ \\
\hline Jumlah & 30 & $100 \%$ \\
\hline
\end{tabular}

Berdasarkan Tabel 1 diatas terlihat bahwa mayoritas responden berpendidikan S1 (Strata Satu) yakni sebanyak 10 orang responden atau 33,3\% dari total responden. Fakta ini mengindikasikan bahwa mayoritas pegawai Institut Pemerintahan Dalam Negeri (IPDN) Kampus Papua dapat dikatakan memiliki kompetensi keilmuan yang baik.

Masa kerja pegawai merupakan masa pegawai tersebut mengabdi dan gambaran pengalaman kerja individu pegawai. Secara lengkap gambaran masa kerja responden dijelaskan pada Tabel 2 dibawah ini :

Tabel 2

Karakteristik Responden Berdasarkan Masa Kerja

\begin{tabular}{|c|c|c|}
\hline Masa Kerja & Jumlah & Persentase \\
\hline $2-5$ Tahun & 15 & $50 \%$ \\
\hline $6-9$ Tahun & 7 & $23,3 \%$ \\
\hline $10-13$ Tahun & 1 & $3,3 \%$ \\
\hline $14-17$ Tahun & 0 & $0 \%$ \\
\hline $18-21$ Tahun & 3 & $10 \%$ \\
\hline $22-25$ Tahun & 0 & $0 \%$ \\
\hline $26-29$ Tahun & 2 & $6,7 \%$ \\
\hline $30-33$ Tahun & 2 & $6,7 \%$ \\
\hline Jumlah & 30 & $100 \%$ \\
\hline
\end{tabular}

Data pada tabel 2 menunjukkan bahwa pegawai dengan masa kerja terendah yakni 2 sampai dengan 5 tahun sebanyak 15 orang atau $50 \%$ dari total responden dan yang tertinggi yakni 30 sampai dengan 33 tahun sebanyak 2 orang atau $6,7 \%$ dari total responden. Data diatas juga menerangkan bahwa masa kerja mayoritas pegawai selama 2 sampai dengan 5 tahun yakni sebanyak 15 orang atau $50 \%$. Gambaran ini mengungkapkan bahwa pegawai Institut Pemerintahan Dalam Negeri (IPDN) Kampus Papua relatif baru 
mengabdi dan belum memiliki pengalaman kerja yang cukup baik dalam menunjang tugasnya.

\section{Uji Regresi}

Berikut ini adalah hasil pengujian dengan menggunakan analisis regresi berganda dengan menggunakan bantuan Software SPSS (Statistikal Package for Social Science) versi 21.0 seperti yang terlihat pada tabel 3 dibawah ini.

Tabel 3

Hasil Analisis Regresi

\begin{tabular}{|c|c|c|c|c|}
\hline Variabel & Standardizied Coefficients & t Hitung & Sig. & Keterangan \\
\hline Constant & 3,850 & & & \\
\hline Legal Audit & 0,087 & 0,774 & 0,446 & Tidak Signifikan \\
\hline Sumber Daya Manusia & 0,422 & 2,171 & 0,039 & Signifikan \\
\hline Komitmen Pimpinan & 0,541 & 2,833 & 0,009 & Signifikan \\
\hline $\mathrm{R}$ & & & & 0,779 \\
\hline R Square & & & & 0,607 \\
\hline Adusted R Square & & & & 0,562 \\
\hline t Tabel & & & & 2,056 \\
\hline $\mathrm{F}$ & & 13,391 & 0,000 & Signifikan \\
\hline F Tabel & & & & 2,834 \\
\hline
\end{tabular}

Dari Tabel 3 diatas bahwa persamaan reresi dalam penelitian ini adalah sebagai berikut :

$$
\begin{aligned}
& Y=a+b 1 X 1+b 2 X 2+b 3 X 3+e \\
& Y=3,850+0,087 X 1+0,422 X 2+0,541 X 3+e
\end{aligned}
$$

Berdasarkan hasil analisis ditemukan bahwa legal audit berpengaruh positif terhadap pengelolaan aset di Institut Pemerintahan Dalam Negeri (IPDN) Kampus Papua namun pengaruhnya tidak signifikan. Hal ini ditunjukkan dengan nilai signifikansi sebesar 0,446 (probabilitas $>0,05)$. Nilai t tabel $>$ t hitung $(2,056>0,774)$ dengan nilai koefisien regresi 0,08 . Hasil pengujian ini menunjukkan bahwa hipotesis pertama ditolak.

Hasil kajian ini mendukung kajian yang dilakukan oleh Syukri \& dan Kartini (2015) dan Raharja (2015) Nurpratiwi dan Wachid (2015) yang telah membuktikan bahwa kualitas 
sumber daya manusia berpengaruh positif dan signifikan terhadap optimalisasi pengelolaan aset. Berdasarkan hasil analisi menunjukkan bahwa sumber daya manusia berpengaruh secara positif dan signifikan terhadap pengelolaan aset di Institut Pemerintahan Dalam Negeri (IPDN) Kampus Papua. Hal ini ditunjukkan dengan nilai signifikansi sebesar 0,039 (probabilitas 0,05 ) nilai t hitung sebesar 2,171 sedangkan $t$ tabel 2,056 sehingga $t$ hitung $>t$ tabel $(2,171>2,056)$ dengan nilai koefisien regresi sebesar 0,422 . Hasil pengujian ini menunjukkan bahwa hipotesis kedua diterima.

Hasil kajian ini mendukung kajian yang dilakukan oleh Syukri \& dan Kartini (2015) yang telah membuktikan bahwa komitmen pimpinan terbukti secara signifikan terhadap optimalisasi pengelolaan aset. Berdasarkan hasil analisis menunjukkan bahwa komitmen pimpinan berpengaruh secara positif dan signifikan terhadap pengelolaan aset di Institut Pemerintahan Dalam Negeri (IPDN) Kampus Papua. Hal ini ditunjukkan dengan nilai signifikansi sebesar 0,009 (probabilitas $<0,05$ ). Nilai t hitung sebesar 2,833 sedangkan $\mathrm{t}$ tabel 2,056 sehingga $t$ hitung $>t$ tabel $(2,833>2,056)$ dengan nilai koefisien regresi adalah sebesar 0,541. Hasil pengujian ini menunjukkan bahwa hipotesis ketiga diterima.

Hasil kajian ini mendukung hasil analisis yang menunjukkan bahwa legal audit, sumber daya manusia dan komitmen pimpinan secara simultan berpengaruh positif dan signifikan terhadap pengelolaan aset di Institut Pemerintahan Dalam Negeri (IPDN) Kampus Papua. Hal ini ditunjukkan dengan nilai signifikansi sebesar 0,000 (probabilitas $<0,05$ ). Nilai $f$ hitung sebesar 13,391 sedangkan $f$ tabel 2,834 sehingga $f$ hitung $>f$ tabel $(13,391>2,834)$. Hasil pengujian ini menunjukkan bahwa hipotesis keempat diterima.

\section{Pembahasan}

Hasil penelitian ini juga menemukan bahwa adanya faktor yang mempengaruhi optimalisasi pengelolaan aset, yaitu sikap atau rasa tanggung jawab dan kepedulian. Sikap peduli dan tanggung jawab sangat diperlukam dalam mengelolan aset atau barang milik negara. Oleh karena itu perlu adanya sikap tanggung jawab yang kuat dan kepedulian yang tinggi dari para pemakai ataupun juga pengurus pengelola aset sehingga proses 
pengelolaan aset berjalan lancar dan aset dapat dipergunakan dan dimanfaatkan dengan baik untuk pelayanan publik dan menjalankan kegiatan pemerintahan.

Pelaksanaan pengelolaan aset yang dimulai dari perencanaan dan penganggaran, pelaksanaan hingga pada tahap pengawasan memang belum sepenuhnya terbebas dari berbagai permasalahan seperti penatausahaan aset yang masih kurang. Hal ini dapat dilihat dari jawaban responden tentang penatausahaan aset dengan rata-rata jawaban responden 2,97 sehingga dapat diindikasikan bahwa pelaksanaan penatausahaan aset di Institut Pemerintahan Dalam Negeri membutuhkan perhatian yang lebih lagi dalam pelaksanaannya.

Pengawasan terhadap pemanfaatan aset masih belum optimal. Hal ini dapat dilihat dari jawaban responden tentang pengawasan pemanfaatan aset dengan rata-rata jawaban responden 3,03 dengan dominan jawaban responden adalah tidak setuju, sehingga dari hasil analisis ini dapat dikatakan bahwa masih perlunya pengawasan yang lebih intensif lagi terhadap pemanfaatan aset oleh pengguna aset apakah aset yang digunakan sudah dimanfaatkan secara efektif dan efisien.

Hasil penelitian juga menunjukkan bahwa ternyata ada status kepemilikan aset khususnya tanah dan bangunan yang relatif masih lemah (ada masalah legal terkait dengan penguasaan tanah dan bangunan tersebut) karena proses hibah dari Pemerintah Daerah Provinsi Papua kepada IPDN yang belum tuntas dan berikutnya adalah pengawasan terhadap proses pemindahan kepemilikan tanah yang juga relatif lemah.

\section{Pengaruh Legal Audit}

Berdasarkan hasil kajian membuktikan secara empiris bahwa hipotesis pertama yang menyatakan Legal Audit berpengaruh signifikan terhadap Pengelolaan Aset ditolak. Berdasarkan hasil analisis regresi, koefisien hubungan antara Legal Audit dengan Pengelolaan Aset dengan nilai signifikansi sebesar 0,446 lebih besar dari 0,05 mengindikasikan bahwa Legal Audit berpengaruh positif namun tidak signifikan terhadap Optimalisasi Pengelolaan Aset. Interpretasi dari temuan hasil penelitian ini menunjukkan bahwa dengan adanya penerapan Legal Audit tidak menjamin Optimalisasi Pengelolaan 
Aset pada Institut Pemerintahan Dalam Negeri (IPDN) Kampus Papua. Hasil kajian ini bertolak belakang dengan hasil kajian empiris oleh Pangayow \& Pratama (2016) yang menyatakan bahwa variabel legal audit berpengaruh positif dan signifikan terhadap optimalisasi aset di pemerintah daerah kota jayapura.

Namun pada hasil kajian empiris oleh Sherly Pauweni Herman Karamoy,Hendrik Gamaliel (2017) menyatakan bahwa legal audit tidak berpengaruh terhadap optimalisasi pengelolaan aset pada pemerintah daerah kabupaten bone bolango. Hal ini disebabkan kurangnya pemahaman para pihak yang terkait dengan barang milik daerah mengenai pentingnya status dan bukti kepemilikan atas aset daerah. Dengan status dan bukti yang kuat atas kepemilikan daerah seharusnya dapat lebih mengoptimalkan penggunaan serta pemanfaatan aset tersebut. Pemerintah daerah masih belum maksimal dalam melakukan legal audit.

Hasil kajian ini juga sejalan dengan teori oleh Siregar (2004) yang menyatakan bahwa legal audit merupakan satu lingkup kerja manajemen aset berupa inventarisasi status panguasaan aset, sistem dan prosedur penguasaan aset atau pengalihan aset, identifikasi dan mencari solusi atas permasalahan aset, strategi untuk memecahkan berbagai permasalahan legal dengan penguasaan ataupun pengalihan aset. Dari hasil jawaban responden tentang legal audit menerangkan bahwa pelaksanaan legal audit di IPDN Kampus Papua sudah dilaksanakan dengan cukup baik, hal ini dapat dilihat dari rata-rata jawaban responden dari setiap item pernyataan didapatkan nilai rata-rata sebesar 4,25 dengan jawaban responden didominasi oleh jawaban setuju. Namun ada beberapa pelaksanaan legal audit ini yang masih perlu ditingkatkan lagi menurut tanggapan dari responden, yaitu dalam hal melengkapi dokumen-dokumen kepemilikan aset untuk mengurangi pertiakian aset karena dokumen kepemilikan aset dengan pihak lain dan pengelola aset yang belum memahami sistem dan prosedur penguasaan atau pengalihan aset. 


\section{Pengaruh Kualitas Sumberdaya Manusia}

Berdasarkan hasil kajian membuktikan secara empiris bahwa hipotesis kedua yang menyatakan Kualitas Sumber Daya Manusia berpengaruh signifikan terhadap Pengelolaan aset diterima. Berdasarkan hasil analisis regresi, koefisien hubungan antara kualitas sumber daya manusia dengan nilai signifikansi sebesar 0,039 lebih kecil dari 0,05 mengindikasikan bahwa kualitas sumber daya manusia berpengaruh secara signifikan dan positif terhadap pengelolaan aset. Interpretasi dari temuan hasil peneltian ini menunjukkan bahwa anatara kualitas sumber daya manusia dengan pengelolaan aset IPDN Kampus Papua menunjukkan arah positif yang berarti peningkatan kualitas sumber daya manusia akan diikuti dengan peningkatan pengelolaan aset.

Untuk mewujudkan percepatan pembenahan administrasi aset haruslah tersedia pegawai yang berkompeten dalam bidang pengelolaan aset. Untuk mendapatkan pegawai yang berkompeten maka diperlukan adanya suatu standar kerja yang perlu disusun dan terstandarisasi sesuai dengan prinsip-prinsip manajemen dan pengembangan SDM, yaitu pegawai yang memiliki pengetahuan tentang aset dan pegawai yang mempunyai sikap terhadap pengelolaan aset. Hasil kajian ini sejalan dengan kajian empiris oleh (Syukri \& dan Kartini, 2015, Darno, 2012 dan Syahputra, Syaukat, \& Irwanto, 2017) yang menyatakan bahwa kualitas sumber daya manusia berpengaruh positif dan signifikan terhadap optimalisasi pengelolaan aset. Hal ini menunjukkan bahwa kualitas sumber daya manusia yang handal akan mempengaruhi optimalisasi pengelolaan aset.

Kajian ini juga sejalan dengan teori dari Mukhyi \& Hudiyanto (1995) yang menyatakan bahwa salah satu sumber daya yang paling penting dalam manajemen adalah sumber daya manusia atau human resource. Pentingnya sumber daya manusia ini, perlu disadari oleh semua tingkatan manajemen termasuk juga manajemen pendidikan islam. Bagaimana majunya teknologi saat ini, namun faktor manusia tetap memegang peranan penting bagi keberhasilan suatu organisasi. Bahkan dapat dikatakan bahwa manajemen itu pada hakekatnya adalah manajemen sumber daya manusia atau sumber daya manusia adalah identic dengan manajemen itu sendiri. Hakekat sumber daya manusia setiap organisasi atau 
perusahaan, khususnya pada lembaga pendidikan diperlukan adanya sumber daya manusia sebagai tenaga kerja. Oleh sebab itu, yang dimaksud sebagai sumber daya manusia adalah tenaga kerja pada suatu organisasi.

Hasil penelitian di IPDN Kampus Papua, menerangkan bahwa kualitas sumner daya manusia yang dimiliki sudah cukup baik, namun dalam segi kuntitas masih kurang. Dari jawaban responden tentang kulitas sumber daya manusia di IPDN Kampus Papua didapatkan nilai rata-rata 4,12. Dari hasil ini juga didapatkan bahwa masih perlunya peningkatan kualitas sumber daya manusia dalam pengelolaan aset di IPDN Kampus Papua seperti pengelola aset sebaiknya berlatar pendidikan akuntansi, jumlah pengelola aset harus cukup dan pelatihan atau bimbingan teknis secara continue diperlukan bagi pegawai yang terlibat dalam pengelolaan aset.

\section{Pengaruh Komitmen Pimpinan}

Berdasarkan hasil kajian yang membuktikan secara empiris bahwa hipotesis ketiga yang menyatakan Komitmen Pimpinan berpengaruh signifikan terhadap Pengelolaan Aset diterima. Berdasarkan hasil analisis regresi, koefisien hunbungan antara Komitmen Pimpinan dengan Pengelolaan Aset dengan nilai signifikansi sebesar 0,009 lebih kecil dari 0,05 mengindikasikan bahwa Komitmen Pimpinan berpengaruh secara signifikan terhadap Pengelolaan Aset. Interpretasi dari temuan hasil penelitian ini menunjukkan bahwa antara Komitmen Pimpinan dengan Pengelolaan Aset IPDN Kampus Papua menunjukkan arah positif yang berarti peningkatan Komitmen Pimpinan akan diikututi dengan peningkatan Pengelolaan Aset. Hasil kajian ini didukung dengan kajian empiris oleh Syukri \& dan Kartini (2015) dan Simamora \& Halim (2015) yang menyatakan bahwa faktor komitmen pimpinan lebih krusial mempengaruhi pengelolaan aset. Hal ini ditandai dengan informasi-informasi yang diperoleh menunjukkan bahwa pimpinan yang tidak memperhatikan masalah aset membuat pengelolaan aset ini menjadi persoalan rumit. Hasil penelitian ini juga membuktikan bahwa komitmen pimpinan adalah faktor yang paling dominan dalam mempengaruhi optimalisasi pengeloaan aset di IPDN Kampus Papua. 
Hasil kajian ini juga didukung oleh teori oleh Maxwell (2001) yang menyatakan bahwa komitmen pimpinan membuka pintu pada prestasi, komitmen berlawanan dengan penolakan, karena komitmen adalah janji serius untuk terus maju dan bangkit. Jadi jika seorang ingin mencapai suatu tujuan maka harus punya komitmen.

\section{SIMPULAN}

Penelitian ini menyimpulkan (1) pengelolaan aset sudah berangsur baik dan mengacu aturan yang berlaku, namun ada beberapa permasalahan masih harus dibenahi, seperti sikap atau rasa tanggung jawab dan kepedulian terhadp asset negara baik oleh pimpinan mauun staf. (2) Legal audit berpengaruh positif namun tidak signifikan terhadap pengelolaan aset. Hal ini menunjukkan bahwa dengan adanya penerapan legal audit tidak menjamin optimalisasi pengelolaan aset. Hal ini disebabkan kurangnya pemahaman para pihak yang terkait dengan pengelolaan aset mengenai pentingnya status dan bukti kepemilikan atas aset. (3) Komitmen pimpinan berpengaruh positif dan signifikan terhadap optimalisasi pengelolaan aset. Hal ini menunjukkan bahwa semakin baik komitmen pimpinan maka optimalisasi pengelolaan aset akan semakin baik pula. Komitmen pimpinan variabel adalah yang paling dominan dalam penelitian ini yang mempengaruhi pengelolaan aset.

Saran yang dapat disampaikan berdasarkan hasil peneltian ini adalah : (1) mengupayakan proses hibah aset tanah dari Pemerintah Provinsi Papua dalam bentuk legal audit melalui proses penerbitan sertifikat kepemilikan, (2) pembangunan fasilitas gudang untuk mengamankan aset khususnya peralatan dan mesin milik IPDN.

\section{DAFTAR PUSTAKA}

Ash-Shidiqie, J. (1996). Sumber Daya Manusia untuk Indonesia Masa Depan. Bandung: Mizan.

Bass, B. M., \& Avolio, B. J. (1990). Transformational leadership development: Manual for the multifactor leadership questionnaire. Consulting Psychologists Press.

Etzioni, A. (1961). Complex organizations: A sociological reader. Holt, Rinehart and Winston.

Fattah, H. N. (2004). Konsep manajemen berbasis sekolah (MBS) dan dewan sekolah. Pustaka Bani Quraisi.

Ghozali, I. (2013). Aplikasi Analisis Multivariate dengan Program IBM SPSS 21 Update PLS. Edisi Ketujuh. Penerbit Universitas Diponegoro. Semarang. 
Gima, S. (2013). Manajemen Aset Pariwisata, Pelayanan Berkualitas Agar Wisatawan Puas dan Loyal, Penerbit Guardaya Intimarta. Bandung (ID).

Grubišić, M., Nušinović, M., \& Roje, G. (2009). Towards efficient public sector asset management. Financial Theory and Practice, 33(3), 329-362.

Hasfi, N. (2013). Pengelolaan Barang Milik Daerah (Suatu Studi Pada Dinas Pendapatan, Pengelolaan Keuangan dan Aset Kabupaten Sintang). Jurnal Program Magister IImu Sosial Universitas Tanjungpura, 1(0001).

Hidayati, Y., Darmayanti, Yeasy, \& Maihendri. (2016). PENGARUH SIKLUS PENGELOLAAN BARANG MILIKDAERAH TERHADAP KUALITAS LAPORAN KEUANGAN (Studi Empiris Pada Pemerintah Kabupaten Solok Selatan). Akuntansi, 8.

Lu, Y. (2011). Public asset management: Empirical evidence from the stategovernments in the United States. Florida Atlantic University.

Mardiasmo, D., \& MBA, A. (2009). Akuntansi Sektor Publik. Yogyakarta: ANDI.

Maxwell, J. C. (2001). Developing the leader within you workbook. HarperCollins Leadership.

Moelyarto, T. (1995). Politik Pembangunan: Sebuah Analisis, Konsep, Arah dan Strategi. Cetakan Ketiga. Yogjakarta: Tiara Wacana.

Mukhyi, A., \& Hudiyanto, H. (1995). Pengantar Manajemen Sumber Daya Manusia. Gunadarma: Depok.

Mulyanto. (2015). Pengaruh Perencanaan Karier, Penilaian Prestasi, Pemberian Tunjangan Kinerja dan Komitmen Pimpinan Terhadap Prestasi Kerja (Studi pada Kantor Pengadilan Negeri di Wilayah EX - Karesidenan Kedu). Jurnal Bisnis \& Ekonomi, 1-22.

Nahartyo, E. (2013). Analisis penatausahaan aset tetap untuk menghasilkan data yang dipercaya dalam laporan barang milik daerah (studi pada Pemerintah Provinsi Maluku). Universitas Gadjah Mada.

Nur Izzaty, K., \& ABDUL ROHMAN, A. R. (2011). Pengaruh Gaya Kepemimpinan Dan Kualitas Sumber Daya Manusia Terhadap Penerapan Anggaran Berbasis Kinerja Badan Layanan Umum (Studi pada BLU Universitas Diponegoro Semarang). Universitas Diponegoro.

Ouda, H. A. G. (2016). Governmental Capital assets: How Far Should the Accounting Recognition of These Assets Go? International Journal on Governmental Financial Management, 16(1), 24.

Pangayow, B., \& Pratama, M. R. (2016). Pengaruh Manajemen Aset terhadap Optimalisasi Pengelolaan Aset Daerah. Jurnal Akuntansi Dan Keuangan Daerah, 11(2).

Pauweni, S., Karamoy, H., \& Gamaliel, H. (2017). Pengaruh Inventarisasi, Legal Audit, Penilaian dan Kondisi Aset terhadap Optimalisasi Pemanfaatan Aset pada Pemerintah Daerah Kabupaten Bone Bolango. JURNAL RISET AKUNTANSI DAN AUDITING" GOODWILL", 8(2).

Pollitt, C., \& Bouckaert, G. (2004). Public management reform: A comparative analysis. Oxford University Press, USA.

Raharja, M. (2015). Pengelolaan Keuangan Dan Aset Daerah (Studi pada Badan Pengelolaan Keuangan dan Aset Daerah, Kabupaten Lamongan). Jurnal Administrasi Publik, 3(1), 111-117.

Salle, A. (2019). Unqualified opinion is not free of corruption: The audit expectation gap in Indonesia. Social Science Research Network.

Salle, A., Mesak, I., \& Yund, H. (2015). Kajian pengelolaan dana otonomi khusus untuk peningkatan pelayanan masyarakat asli Papua. (Akbar Silo, Ed.) (Kedua). Jayapura: Uncen Press. Retrieved from http://repository. $m$ kduncen.ac.id/index.php?p=fstream\&fid=8\&bid=7 
Simamora, R., \& Halim, A. (2015). Faktor-faktor yang mempengaruhi pengelolaan aset pasca pemekaran wilayah dan pengaruhnya terhadap kualitas laporan keuangan Pemerintah di Kab. Tapanuli Selatan. Jurnal Ekonomi Dan Bisnis, 10(1).

Siregar, D. (2004a). Manajemen Aset, Jakarta: PT. Gramedia Pustaka Utama.

Siregar, D. (2004b). Manajemen Aset. Jakarta. Satyatama Graha Tara.

Sugiyono, P. D. (2013). Metode Penelitian Manajemen. Bandung: Alfabeta, CV.

Syahputra, K., Syaukat, Y., \& Irwanto, A. K. (2017). Strategi peningkatan pengelolaan barang milik daerah pada Pemerintah Kabupaten Kepulauan Anambas. Jurnal Manajemen Pembangunan Daerah, 9(2).

Syukri, S., \& dan Kartini, H. (2015). Pengaruh Inventarisasi Aset Kualitas Sumber Daya Manusia dan Komitmen Pimpinan terhadap Optimalisasi Pengelolaan Aset dan Kualitas Laporan Keuangan Pemerintah Daerah Kabupaten Takalar. Master Theses Hasanuddin University, published on http://repository. unhas ....

Wirawan, R., \& Nurpratiwi, R. (2015). Partisipasi masyarakat dalam perencanaan pembangunan daerah. JISIP: Jurnal IImu Sosial Dan IImu Politik, 4(2).

Yasmadi, M. P. (2002). Kritikan Nurchlish Madjid Terhadap Pendidikan. Jakarta: Ciputat Press. 